\title{
IMPACT OF OBSTETRICIAN/GYNECOLOGIST HOSPITALISTS ON RESPONSE TIME OF OBSTETRIC EMERGENCY OPERATION IN SARDJITO GENERAL HOSPITAL YOGYAKARTA INDONESIA: A RETROSPECTIVE COHORT STUDY
}

\author{
Eugenius Phyowai Ganap ${ }^{1}$, Mohammad Hakimi², Soerjo Hadijono ${ }^{3}$, Ova Emilia ${ }^{4}$
}

\begin{abstract}
ABSTRAK
Latar Belakang: Model dokter jaga on-site dalam pelayanan Obstetri telah banyak dikenalkan pada dekade terakhir, dan memiliki peran penting dalam pelayanan obstetri dan berpengaruh pada luaran maternal dan neonatal.

Tujuan: Penelitian ini mengevaluasi pengaruh implementasi dokter jaga on-site dengan waktu tanggap pelayanan operasi.

Metode: Penelitian ini merupakan studi kohort retrospektif yang melibatkan partisipan sebelum dan setelah implementasi kebijakan dokter jaga on-site sejak Oktober 2013 hingga September 2014. Luaran yang diukur adalah waktu tanggap dan faktor-faktor yang berpengaruh terhadap waktu tanggap.

Hasil dan Pembahasan: Sejumlah 71 pasien dimasukan dalam studi ini (30 pada kelompok jaga on-call dan 41 kelompok jaga on-site). Analisis univariat menunjukkan waktu tanggap rata-rata kelompok dokter jaga on-site lebih cepat dan secara statistik berbeda bermakna dibanding kelompok dokter jaga on-call $(65,3 \pm 25,89$ vs $84 \pm 22,29$ menit; $p=0,002)$. Analisis multivariat menunjukkan faktor rumah sakit yang berkontribusi adalah kesiapan ruang operasi.

Kesimpulan: Implementasi model dokter jaga on-site berhubungan secara signifikan dengan perbaikan waktu tanggap dalam pelayanan darurat obstetri.
\end{abstract}

Kata kunci: Mortalitas Maternal, Jaga On-Site Rumah Sakit, Seksio Sesarea, Waktu Tanggap

\begin{abstract}
Background: The hospitalist model in obstetric care which was introduced over the last decades now has an important role in care delivery management with the potential positive impact on maternal and neonatal outcomes.

Objective: The aim of this study was to evaluate the effect of hospitalist model towards surgical emergency response time.

Method: This research design was cohort a retrospective study. Participants included were the patient in the time before and after implementation of obstetrician/gynecologist full-hospitalist policy during October 2013 until September 2014. The outcome measured were mean response time and possible hospital factors which contribute to response time.

Result and Discussion: We included a total of 71 patients (30 on-call obstetrician group and 41 full-time hospitalist group). Univariate analysis indicated mean response time was significantly differ in full-time hospitalist group when compared to the on-call obstetrician group $(65.3 \pm 25.89$ vs. $84 \pm 22.29$ mins; $p$
\end{abstract}

1,2,4 Faculty of Medicine Universitas Gadjah Mada - Sardjito General Hospital

3 Faculty of Medicine Universitas Diponegoro - Karyadi General Hospital 
$=0.002$ ). Multivariable analysis determined that hospital factors which contribute to response time are readiness of operating theatre.

Conclusion: Implementation of full-time hospitalist model is associated with a significant improvement of response time in emergency obstetric care.

Keywords: Maternal mortality, Obstetrician/Gynecology Hospitalist, C-section, Response Time.

\section{BACKGROUND}

Indonesia which had many significant achievements on societal, political, and economic development, still struggles with high rate of maternal death. Descriptive data from 2012 Indonesia Demographic and Health Survey (IDHS) has shown that, maternal mortality ratio increased significantly from 228 per 100.000 live births in 2007 became 359 per 100.000 live births in 2012. ${ }^{1,2}$ World Health Organization (WHO) estimated there were 8.800 mothers died from 4.5 million live births in 2013. ${ }^{3}$ The direct obstetric causes still the major causes of all deaths. Obstetric complication such as hemorrhage, hypertensive disorders, and sepsis accounted for $80 \%$, and all other direct causes of death is about $20 \%{ }^{4}$

The conceptual framework developed by Thaddeus and Maine ${ }^{5}$ identify "three delays model" as significant contributors in maternal deaths, which are (1) delay in deciding to seek care $^{2}$ delay in identifying and reaching health facility, and ${ }^{3}$ delay in receiving adequate and appropriate treatment. Delay in accessing maternal health care is still being the barrier in Indonesia, include limited availability of health staff and limited infrastructure or facilities. ${ }^{6}$

In order to reduce maternal mortality rate, it requires good medical strategies, one of strategy is to optimalization the provision of emergency maternal care. The key indicator in emergency maternal care provision is emergency response time. Response time is interval between call receipt, arrival on scene and provision of service for the patient. The availability of obstetrician/ gynecologist hospitalists and also health facilities provide variety in results toward emergency response time.

One of the problem faced by Sardjito General Hospital as tertiary referral hospital for maternal care in Yogyakarta Special Region is limited facilities which will implicated to delay in preparation of surgery (i.e. Caesarean Delivery). The emerging model was introduced over the last decades, which called "hospitalist medicine" or "hospitalist". Hospitalist as described by Wacther and Goldman in New England Journal of Medicine article "The emerging role of 'Hospitalists' in the American Health Care System" is a physician whose primary focus is in the inpatient medical care. ${ }^{7}$ Specifically, obstetrician/gynecologist (ob/ gyn) hospitalist is a 24-hour a day/7-day a week physician who assists or who is employed by the hospital to manage laboring patients, obstetric triage and emergencies. ${ }^{8}$ Since April 2014, Sardjito General Hospital have already enforced implementation of obstetrician/gynecologist hospitalists with the goal to shorten emergency response time for surgery.

The purpose of this study is to explore the impact of obstetrician/gynecologist hospitalists on the factors associated with emergency response time and to compare emergency response time between before and after implementation of obstetrician/gynecologist hospitalists policy. 


\section{METHOD}

\section{Study design, site and sampling methods}

This is a cohort study conducted in Emergency Department of Sardjito General Hospital, Yogyakarta Special Region Province, Indonesia in the period of October 2013 - September 2014. With a purposive sampling technique, 71 samples were obtained from the population who received crash emergency caesarean section.

\section{Participants}

The population is the pregnant women patients in Emergency Department of Sardjito General Hospital and who have to received emergency caesarean section in the period of study. The participants included is the patient in the time before and after implementation of obstetrician/gynecologist hospitalists policy. Emergency caesarean sectons were defined as unscheduled caesarean deliveries performed before or during labour and designated as such in the operative report by the surgeon.

\section{Data Collection and analysis}

Information on demographic characteristic, gestational ages, parity status, labor course and indication for caesarean section were collected. Emergency response time or decision-to-delivery interval, defined as the duration between the time the decision was made to the time the baby was delivered by emergency caesarean section (in minutes) was recorded for each patient.

The primary outcomes measured in this study were the factors associated with emergency response time and to compare emergency response time between before and after implementation of obstetrician/gynecologist hospitalists policy.

Statistical analysis was performed using SPSS 16 (SPSS Inc., Chicago, Illinois, USA). Demographic and pregnancy characteristics in the 'before or on-call obstetrician' and 'after or full-time hospitalist' implementation of policy were compared. A normality test was conducted for continuous data with Shapiro-Wilk test ( $p>$ 0,05 indicated normal distribution) before each analysis. For normally distributed data, Student's t-test was performed to compare data between two groups ('Before' and 'After'), and for nonnormally distributed data the Mann-Whitney test was performed. Categorical variables were compared with bivariate analysis using ChiSquare test. Multivariate analysis was performed to explore the factors which has significant association with emergency response time. Tests with $p<0,05$ were considered statistically significant.

The Medical and Health Research Ethics Committee Faculty of Medicine Universitas Gadjah Mada and Dr. Sardjito Hospital approved the study protocol and released the ethical clearance (No. KE/FK/371/EC).

\section{RESULT AND DISCUSSION}

\section{Characteristics of the study subjects}

During the time periods described six months before and after implementation of the policy (October 2013 - March 2014 and April 2014 - September 2014), data were reviewed on 30 cases and 41 cases respectively. Demographic and clinical variables are compared between two groups in Table 1. 
Table 1 The mean response time based on before and after implementation of hospitalist policy

\begin{tabular}{cccc}
\hline Variables & $\begin{array}{c}\text { On-call Obstetrician } \\
(\mathrm{n}=30)\end{array}$ & $\begin{array}{c}\text { Full-time Hospitalist } \\
(\mathrm{n}=41)\end{array}$ & P value \\
\hline Mean response time, (mins) & $84 \pm 22.29$ & $65.3 \pm 25.89)$ & 0.002 \\
\hline
\end{tabular}

Table 2 The characteristics of subjects grouped based on before and after implementation of hospitalist policy

\begin{tabular}{lccc}
\hline Variables & $\begin{array}{c}\text { On-call Obstetrician } \\
(\mathrm{n}=30)\end{array}$ & $\begin{array}{c}\text { Full-time Hospitalist } \\
(\mathrm{n}=41)\end{array}$ & P value \\
\hline $\begin{array}{l}\text { Gestational age, } \mathrm{n}(\%) \\
<37 \text { weeks }\end{array}$ & $8(11.3)$ & $21(29.6)$ & 0.03 \\
$\quad \geq 37$ weeks & $22(31.0)$ & $20(28.2)$ & \\
$\begin{array}{l}\text { Parital status, } \mathrm{n}(\%) \\
\quad<3\end{array}$ & $25(35.2)$ & $28(39.4)$ & 0.15 \\
$\quad>3$ & $5(7.0)$ & $13(18,3)$ & \\
$\begin{array}{l}\text { Birthweight, (grams) } \\
\quad<2500\end{array}$ & $14(19.7)$ & $23(32.4)$ & 0.43 \\
$\quad \geq 2500$ & $16(22.5)$ & $18(25.4)$ & \\
APGAR Score & & & \\
$\quad<7$ & $18(25.4)$ & $27(38.0)$ & 0.61 \\
$\geq 7$ & $12(16.9)$ & $14(19.7)$ & \\
\hline
\end{tabular}

The mean response time was significantly quicker in full-time hospitalist group when compared to the on-call obstetrician group ( $p=$ 0,002 ). Neonates in full-time hospitalist group were delivered significantly more preterm pregnancy $(p=0,03)$ than on-call obstetrician group. There were no differences between the two groups for parity birth weight and APGAR Score.

\section{Factors associated with response time}

We performed multivariable analysis with logistic regression test to determine which factors contributed to response time in this study. The result showed that full-time hospitalist implementation (OR 11.02; 95\% Cl: 2.3 - 52.7; p $=0.03)$ and readiness of operating theatre (OR 9.82; 95\% Cl: 1.03-93.79; $p=0.04$ ) has significant contribution to quicker response time.

Table 3 Multivariate analysis among variables that contribute to response time

\begin{tabular}{lccc}
\hline \multicolumn{1}{c}{ Variables } & OR & Cl (95\%) & p value \\
\hline Full-time hospitalist implementation & 11.02 & 2.30 .52 .70 & 0.03 \\
Readiness of perinatologist & 2.292 & $0.29-17.80$ & 0.42 \\
Readiness of anesthetist & 3.51 & $0.47-26.41$ & 0.22 \\
Readiness of operating theatre & 9.82 & $1.03-93.79$ & 0.04 \\
\hline
\end{tabular}


The implementation of full-time hospitalists in this study shows significantly improvement of obstetric care delivery. We found hospitalists could reduce response time significantly. Reduction in response time could improved clinical management. Previous study shows the decision to incision interval of more than 30 minutes associated with higher incidence of adverse neonatal outcome, such as admission to the neonatal intensive care unit. ${ }^{9}$

Our study results as shown in Table 1 , the mean response time is significantly quicker in full-time hospitalists group compared to another group $(65.3 \pm 25.89$ mins vs. $84 \pm 22.29$ mins; $p=0.002)$. Although the mean response time significantly improved, this results are still above the expected response time as recommended by RCOG/NICE guidelines. The National Institute for Health and Clinical Excellence (NICE) recommends delivery should be accomplished within 30 minutes where possible in cases of confirmed or suspected fetal compromised. ${ }^{10}$ Interestingly, Sibuea (2007) found that the incidence of severe asphyxia and neonatal mortality in emergency SC is higher than elective SC and vaginal delivery. ${ }^{11}$

Our findings showed that several factors associated with response time improvement in this research including the implementation of fulltime hospitalists itself and readiness of operating theatre. The finding that implementation of full-time hospitalists are more likely to have quicker response time in obstetric emergency management. This may be explained by the concept of full-time hospitalists in which provide 24-hour a day in-house obstetrician. This concept is proposed to improve patient safety, reduce response time, and make more efficient clinical management. ${ }^{12}$ The hospital factor that also evaluate in this study is readiness of operating theatre which has significant contribution to response time improvement. OB/GYN hospitalist program cost in Sardjito General hospital during the implementation of the policy at least 11.25 million per day or 337.5 million rupiahs per month.

\section{CONCLUSION}

Implementation of full-time hospitalist model is associated with a significant improvement of response time in emergency obstetric care. It is recomended that hospitals that provide comprehensive and emergency obstetric care assign this model to reduce maternal health.

\section{REFERENCES}

1. Badan Pusat Statistik-Statistics Indonesia (BPS) National Family Planning Coordinating Board Ministry of Health ORC Macro: Indonesia Demographic and Health Survey 2007. Calverton, Maryland: BPS and ORC Macro. 2008. https://dhsprogram.com/pubs/pdf/FR218/ FR218\%5B27August2010\%5D.pdf

2. Statistics Indonesia (Badan Pusat StatistikBPS), National Population and Family Planning Board (BKKBN), and Kementerian Kesehatan (Kemenkes-MOH), and ICF International. 2013. Indonesia Demographic and Health Survey 2012. Jakarta, Indonesia: BPS, BKKBN, Kemenkes, and ICF International. https://dhsprogram.com/pubs/pdf/ FR275/FR275.pdf

3. WHO, UNICEF, UNFPA and The World Bank estimates. Trends in maternal mortality: 1990 to 2013. http://apps.who.int/iris/bitstream/ 10665/ 112682/2/9789241507226_eng.pdf

4. Putra, M.P., Yudha, editors. Menkes: Angka Kematian Ibu Melahirkan Masih Tinggi [Internet]. Jakarta: Republika;2013 [cited 2013 May 5]. Available from: http://www.republika.co.id/berita/ nasional/daerah/13/02/16/mi9ugy-menkes-angkakematian-ibu-melahirkan-masih-tinggi

5. Thaddeus S, Maine D. Too far to walk : maternal mortality in context. Soc Scie Med. 1994 Apr; 38(8):m 1091-110.

6. Widawati. Faktor yang mempengaruhi pola pemilihan penolong persalinan di kecamatan bojongloa kidul, kota bandung tahun 2007 [thesis]. Universitas Indonesia; 2008. 
7. Wachter RM, Goldman L. The emerging role of "hospitalists" in the American health care system. N Engl J Med 1996; 335:514-7.

8. Olson R, Garite TJ, Fishman A, Andress IF. Obstetrician/gynecologist hospitalists: can we improve safety and outcomes for patients and hospitals and improve lifestyle for physicians?. Am J Obstet Gynecol 2012; 81-6.

9. Chauhan SP, Roach H, Naef RW, et al. Cesarean section for suspected fetal distress. Does the decision-incision time make a difference? J Reprod Med 1997; 42:347-52
10. National Institute for Health and Care Excellence. Clinical Guideline : Caesarean Section. London, UK : NICE 2011.

11. Sibuea H. 2007. Manajemen Seksio Sesarea Emergensi: Masalah dan Tantangan. Pidato pengukuhan Guru Besar Bidang Kebidanan dan Penyakit Kandungan Universitas Sumatera Utara.

12. Olson R, Thomas JG, Fishman A. et al. Obstetrician/ gynecologist hospitalists: can we improve safety and outcomes for patients and hospitals and improve lifestyle for physicians. American Journal of Obstetrics and Gynecology 2012. 81-86. 